New Zealand National Society for Earthquake Engineering

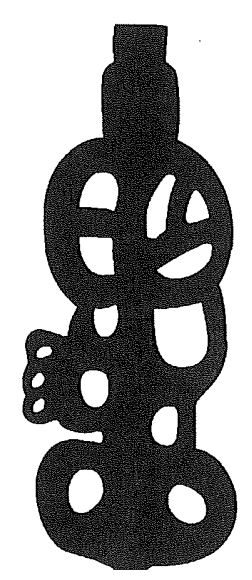

POST-EARTHQUAKE BUILDING SAFETY EVALUATION PROCEDURES

\author{
PREPAREDNESS CHECKLIST \\ and \\ RESPONSE PLAN \\ for \\ TERRITORIAL AUTHORITIES
}




\section{POST-EARTHQUAKE BUILDING SAFETY EVALUATION PROCEDURES}

\section{CONTENTS}

Foreword

Basic Aims

Background

Scenario

Section One: Context

1.1 Need for a Response Plan

1.2 Post-earthquake Building Inspections

1.3 Rapid Evaluations

1.4 Detailed Evaluations

1.5 Evaluations and the Building Act

1.6 Key References

Section Two: Preparing the plan

2.1 Preparedness Checklist

2.2 Building Evaluation Manager (BEM) Tasks

2.3 Administration Officer (AO) tasks

Section Three: Sample Building Safety Evaluation Response Plan

3.1 Authority and Scope

3.2 Activation

3.3 Organisation and Staffing

3.4 Outline Procedures

3.5 Administration

3.6 Material Requirements

Appendices:
A. Safety Assessment Forms
B. Recommended Placards
C. List of Essential Items to be Provided to Inspectors
D. Example Telephonist Form
E. Bibliography

\section{FOREWORD}

\section{BASIC AIMS OF DOCUMENT}

The primary aim of this document is to provide Territorial Authorities with an outline response plan so that safety evaluations of damaged buildings can be activated efficiently and effectively following a major earthquake (or any other disaster which affects buildings). Services such as drainage, water supply and roading are not included within the scope of this document.

Territorial Authorities have the responsibility for providing the planning framework, within which a range of professional groups can operate. These include structural and civil engineers, building inspectors, and loss adjusters.

It is intended that these Building Safety Evaluation Procedures will be adopted by all New Zealand Territorial Authorities to avoid the need for each to formulate their own.

National acceptance of these procedures will also mean that only one set of forms, placards, information management systems, training resources etc. need be prepared. A common standard also makes the use of external inspection resources more practicable.

This document confines its scope to Territorial Authority planning for building damage assessment during the emergency phase of a disaster. Further plans for activities arising in the restoration phase are also required. They include:

- definition of structural standards for the repair of damaged buildings

- streamlined procedures for building consents

- streamlined procedures for resource consents, including debris disposal and land use

- transfer of information to insurance firms

\section{BACKGROUND}

A New Zealand National Society for Earthquake Engineering Study Group was set up in March 1995 to provide guidelines for the emergency response of both Territorial Authorities and the Society's own members in the event of a damaging earthquake occurring in New Zealand. This publication has been prepared for use by Territorial Authorities.

The membership of the Study Group includes people with diverse interests in emergency period building safety evaluations following an damaging earthquake. The study group consisted of Andrew Charleson, Convenor (Victoria University of Wellington School of Architecture), Maurice Clarke (Insurance Council), Andrew King (BRANZ), David Middleton (EQC), Tom Newell (Wellington City Council), Kevin O'Kane (Ministry of Civil Defence), Paul Phillips (AMP/BOMA), Rachel Scott (WCC Emergency Management Office), Richard Sharpe (Beca Carter Hollings \& Ferner Ltd), Bruce Shephard (Opus Consultants) and George Skimming (Wellington City Council).

Given that in recent years no New Zealand city has experienced significant earthquake damage, the Study Group has drawn heavily upon North American experience, and in particular, upon:

\section{ATC-20 Procedures for postearthquake safety evaluation of buildings and \\ ATC-20-2 Addendum to the ATC-20 postearthquake building safety procedures.}

The building evaluation methodology presented in these procedures is similar to that outlined in these two publications, but incorporates a different approach to placard use. Inspection notebooks, a training package and a management guide as 
provided within the ATC-20 framework are not yet available in a New Zealand version. Refer to the Bibliography for full publication details.

A first draft of this document was published in October 1996. Copies were sent to all Territorial Authorities and interested parties for a six month period during which comments were received and considered for incorporation into the final document.

\section{DISASTER SENARIO}

The importance of a Territorial Authority being prepared for a disaster becomes apparent when a realistic probable disaster scenario is considered.

This document envisages a scenario where there is extensive damage to buildings (residential, commercial or industrial) and infrastructure (roads, bridges, water supplies, electricity supply, telephone communications etc) over a large area, and where people are likely to have been killed and injured, possibly numbering in the hundreds. While the document is generally based on the situation following a large earthquake, the principal actions, operations and procedures are equally applicable to other disaster situations.

Following any major damaging event that disrupts and threatens life and normal activities, there is likely to be shock, confusion and chaos in the period following, and lasting some appreciable time. All people, whether the general community, or those attempting to help in or manage the emergency response as individuals or in organisations, will be subject to all human emotions in all manner of ways. All participants are potential victims of the disaster.

Amidst such a disaster, a scene of apparent disruption, chaos and emotion, actions are required to respond to the emergency and to start the process of recovery. An important action is to address the safety of buildings, to establish those that cannot be used, to make those damaged safe so that they can be used, and to identify those that can continue to be fully used.

There will be a mix of extent of damage to buildings within an area and between different areas and localities. Buildings may not be damaged, may feature broken glass, may have sunken or be tilting, may be cracked, broken or distorted, and may have partially or fully collapsed. Buildings of different age, form and construction material are likely to suffer different extents of damage. Many buildings at first sight may appear to be undamaged, but on closer inspection these may be found to be perhaps severely damaged. Very often the full extent of damage continues to emerge over time.

The safety state of buildings and debris from damaged buildings can affect both the internal contents and use, as well as adjacent use of other buildings, roads and other services with all the interdependencies of community infrastructure facilities. Buildings are a major source of secondary damage effects which can continue throughout the period of the disaster, eg falling objects, fire, chemical hazard, leaking water and sewer lines, electrical hazards and so on.

The task is to determine what buildings and areas can and cannot be generally used, what is necessary to reduce danger from and around damaged buildings, and to establish what if anything has to be done to allow the continued operation of essential services buildings.

Quantified assessment of building damage is necessary to determine reconstruction programmes and resource requirements for repair and restoration:

- money

- technical and approvals documentation

- labour

- machinery

- construction materials

and to assess how long recovery may take. Quantified assessment of building damage is also necessary to manage the overall recovery process co-ordinated with restoration of lifelines and utilities or temporary facilities.

The following preparedness actions and response plan will assist a Territorial Authority to respond to and manage building safety inspection activities for such an event, to meet its responsibilities, and to be seen to have been effective and efficient.

\section{SECTION ONE: CONTEXT}

\subsection{NEED FOR A RESPONSE PLAN}

The response plan outlined in this document is intended to be activated immediately after a state of civil defence emergency is declared following a damaging earthquake, or in any other circumstances where significant numbers of buildings have suffered damage.

Territorial Authorities (TAs) have the responsibility of coordinating building inspections to provide for public safety. People need to be kept from entering or using unsafe buildings, or be informed that essential activities may continue where structures are assessed as safe. Authorities will be under intense media, public and political pressure to manage the inspection process well. Authority for TAs to undertake these activities is vested in them through the Civil Defence Act and Section 70 of the Building Act 1991.

Other important short-term aims for inspections include:

- safety of search and rescue operations

- safe use of streets adjacent to damaged buildings

- safe occupation of buildings and their continued use, especially emergency facilities

- assessment of the need for temporary works such as shoring, temporary securing and making safe

- saving property from unnecessary demolition 
Inspections also contribute to longer-term recovery measures, by assisting with:

- cost of damage estimates

- determining the aid and resources required for permanent recovery

- obtaining engineering, scientific and insurance data to improve disaster mitigation measures.

\subsection{POST EARTHQUAKE BUILDING INSPECTIONS}

A variety of inspections are required following an earthquake severe enough to warrant a state of emergency being declared. They are listed and summarised in Figure 1.

Territorial Authorities are responsible primarily for the Rapid and Detailed Evaluations. However, they may also be requested to provide structural engineering assistance for Entry inspections and to provide advice during rescue operations.
A flow chart describing the Rapid and Detailed Evaluation procedures is presented in Figure 2. Although Territorial Authorities are not involved directly in Engineering Evaluations, which are considered part of the earthquake restoration phase, they must plan for the efficient processing of many and urgent building consent applications.

These inspections will require the mobilisation of all available inspection resources.

Territorial Authority (TA) staff may need to be supplemented by appropriately skilled persons, both local and distant. It is desirable that all TA staff and additional inspectors are familiar with the Rapid and Detailed Evaluation procedures as described in this and supporting documents.

Planning for these inspections before an emergency will improve response time and effectiveness, and reduce public concerns.

\begin{tabular}{|c|c|c|c|c|c|}
\hline Title & Timing* & Initiated by & Purpose & Conducted by & Comment \\
\hline $\begin{array}{l}\text { initial } \\
\text { (drive by/ } \\
\text { windscreen) }\end{array}$ & $\begin{array}{l}\text { within } \\
\text { hours after } \\
\text { event }\end{array}$ & $\begin{array}{l}\text { CD staff, } \\
\text { emergency } \\
\text { service action } \\
\text { plans }\end{array}$ & $\begin{array}{l}\text { assess aggregate } \\
\text { damage for affected } \\
\text { area }\end{array}$ & $\begin{array}{l}\text { Emergency } \\
\text { services, TA staff, } \\
\text { CD volunteers }\end{array}$ & $\begin{array}{l}\text { no entry of premises, no } \\
\text { formal records, emphasis on } \\
\text { total numbers of collapses, } \\
\text { identify rescue tasks etc }\end{array}$ \\
\hline entry & $\begin{array}{l}\text { within } \\
\text { first day }\end{array}$ & $\begin{array}{l}\text { NZ Fire } \\
\text { Service, } \\
\text { Police, } \\
\text { rescuers }\end{array}$ & $\begin{array}{l}\text { ascertain safety needs } \\
\text { of searchers/rescuers, } \\
\text { record search results, } \\
\text { prioritise rescues } \\
\text { (triage) }\end{array}$ & $\begin{array}{l}\text { NZ Fire Service, } \\
\text { other emergency } \\
\text { groups, rescue } \\
\text { teams; engineers } \\
\text { may be asked to } \\
\text { advise }\end{array}$ & $\begin{array}{l}\text { short-term assessment } \\
\text { focused on likely hazard to } \\
\text { victims or rescue workers, } \\
\text { shorthand marks made on } \\
\text { buildings as hazard and } \\
\text { evacuation reference }\end{array}$ \\
\hline $\begin{array}{l}\text { rapid } \\
\text { (safety) }\end{array}$ & $\begin{array}{l}1 \text { to } 14 \\
\text { days }\end{array}$ & $\begin{array}{l}\text { Building } \\
\text { Evaluation } \\
\text { Manager } \\
\text { (BEM) }\end{array}$ & $\begin{array}{l}\text { ascertain extent of } \\
\text { damage and hazards; } \\
\text { assess appropriate } \\
\text { level of occupancy; } \\
\text { note security and } \\
\text { shoring requirements }\end{array}$ & $\begin{array}{l}\text { personnel from the } \\
\text { building industry, } \\
\text { architects }\end{array}$ & $\begin{array}{l}\text { formal system, placards } \\
\text { posted on buildings, central } \\
\text { record maintained, note } \\
\text { made of sites needing further } \\
\text { (detailed) inspections, unsafe } \\
\text { areas cordoned off }\end{array}$ \\
\hline detailed & $\begin{array}{l}2 \text { to } 21 \\
\text { days }\end{array}$ & BEM & $\begin{array}{l}\text { further inspection as } \\
\text { identified by Rapid } \\
\text { Evaluations or } \\
\text { subsequent requests, } \\
\text { dealing with complex } \\
\text { or critical facilities }\end{array}$ & $\begin{array}{l}\text { structural engineers, } \\
\text { building services } \\
\text { and geotechnical } \\
\text { engineers }\end{array}$ & $\begin{array}{l}\text { formal system, revised } \\
\text { placards posted on buildings, } \\
\text { central record updated, } \\
\text { unsafe areas cordoned off }\end{array}$ \\
\hline engineering & $\begin{array}{l}\text { longer- } \\
\text { term }\end{array}$ & $\begin{array}{l}\text { owners, } \\
\text { insurance } \\
\text { companies }\end{array}$ & $\begin{array}{l}\text { establish long-term } \\
\text { future of buildings, } \\
\text { establish losses for } \\
\text { insurance purposes }\end{array}$ & $\begin{array}{l}\text { engineers, architects } \\
\text { and loss adjusters }\end{array}$ & $\begin{array}{l}\text { meets insurance and } \\
\text { restoration requirements } \\
\text { under the Building Act }\end{array}$ \\
\hline
\end{tabular}

FIGURE 1: Summary of post-earthquake building inspections 
Notification by owner

Noted in initial inspection

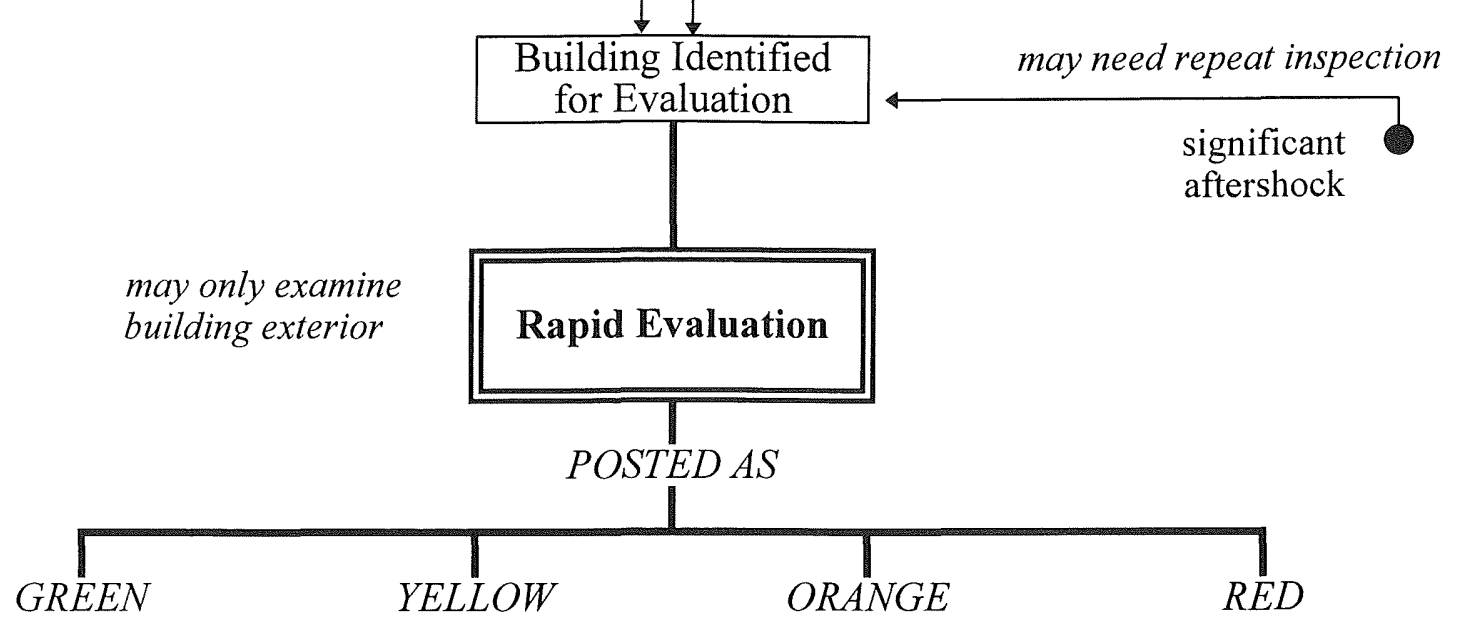

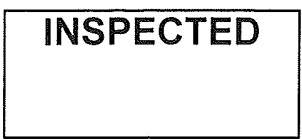

apparently $O K$; no restrictions on use or entry

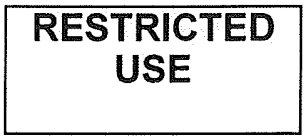

some concerns; parts may be off limits; use may be restricted

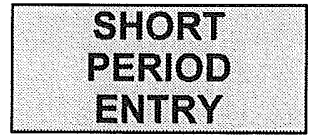

significant concerns; enter only on urgent business; leave as quickly as possible

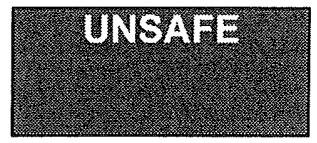

clearly unsafe; do not enter without written permission

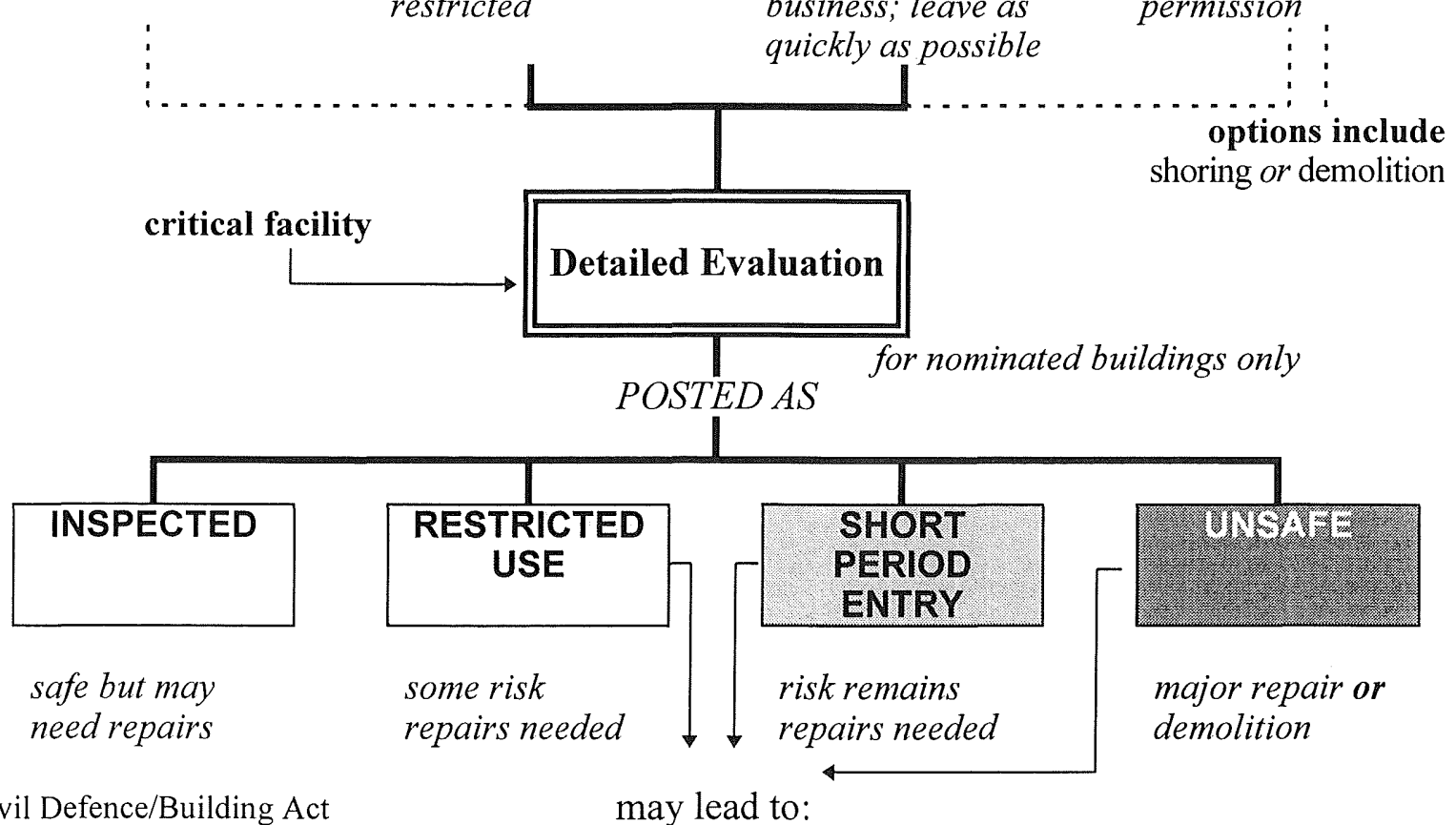

Building Act

\section{Engineering Evaluation}

FIGURE 2: Flow Chart, showing the normal evaluation and posting process (adapted from ATC-20) 
1.3

\section{RAPID EVALUATIONS}

During a Rapid Evaluation each field inspection team should consist of two technical inspectors accompanied by a person with good inter-personal skills to attend to occupants' queries and concerns while the inspection is undertaken.

Inspectors will quickly assess the type and extent of building damage using an assessment form as a guide, and on the basis of that inspection will post a placard on the building:
- inspected
- restricted use
- short period entry
- unsafe
GREEN

YELLOW

ORANGE

$R E D$
Copies of safety assessment forms and placards are in Appendices A and $\mathrm{B}$ respectively.

Further actions to improve safety in and around the building may be identified, and the inspectors may cordon off some areas or recommend a Detailed Evaluation be carried out. Rapid Evaluations may be undertaken by building inspectors, experienced building contractors, and suitably experienced building professionals. Local professional engineering resources will initially be focused on critical facilities and those enterprises which have arranged inspection contracts in such an event. Conservation of structural engineering resources, for performing Detailed Evaluations, is a likely requirement.

\subsection{DETAILED EVALUATIONS}

A Detailed Evaluation will be performed on all critical facility buildings, and on any other buildings where the Rapid Evaluation identifies the need for further assessment.

Multi-storey buildings will need a Detailed Evaluation if initially assessed by inspectors lacking reinforced concrete or structural steel seismic design skills. Structural and building services engineers are required for these evaluations, supplemented as required by geotechnical engineers. The outcome of this process is a completed (detailed) assessment form (Appendix A) and an appropriate placard, possibly revising the initial posting.

\subsection{EVALUATIONS AND THE BUILDING ACT}

There has been considerable discussion, which is continuing, on the legal context in which inspections can occur. The Society notes that the comments below do not constitute a legal opinion, and accepts no liability for any interpretation made.

There is a clear difference, under current legislation, between the options available during a declared state of civil defence emergency, and those available after its termination. Some of the relevant provisions are listed below.

The Civil Defence Act 1983 allows for exclusion of persons from premises (s60), emergency entry on premises (s61) and provides protection from liability for persons acting under the instructions of a civil defence controller (s66). These provisions only apply while a state of civil defence emergency is in force. There is no specific provision related to placing notices.

The Building Act 1991 has general provisions related to inspections (s76) which allow the Territorial Authority to take "reasonable steps" to ensure that buildings remain safe and sanitary. Property owners are required to "give every reasonable facility" to allow such inspections. Legal opinions received to date indicate that the placards suggested in these guidelines do not constitute official notices (under s65, s71). Other sections of the Building Act relevant to the period following a damaging earthquake include:

- $\quad$ s70 authorises Territorial Authorities to take measures to avert immediate danger.

- $\quad$ ss $32(2)(\mathrm{ba})$ and $32(2 \mathrm{~A})$ permit urgent building work to commence without obtaining a building consent in advance provided that all reasonable steps are taken to obtain a building consent as soon as practicable after the work has begun.

- $\quad$ s38 specifies what, if any, upgrading must be undertaken when a building is being altered and alteration includes repair.

- $\quad$ s7 specifies that all work shall comply with the building code but s33(4) gives Territorial Authorities extensive powers to waive or modify the provisions of the building code.

- $\quad$ s33(5) places no limits on the acceptance of producer statements provided only that the Territorial Authority is to be satisfied on reasonable grounds as to compliance with the building code. In other words, a Territorial Authority may accept that a producer statement is, or contributes to, reasonable grounds for that purpose.

- $\quad$ s83 provides a statutory defence against prosecutions for actions taken in emergency situations due to natural disasters.

- $\quad$ s25 permits a Territorial Authority to transfer its powers under the Building Act to another Territorial Authority.

The Society has initiated discussions with government agencies which may result in pursuing amendments to relevant legislation.

\subsection{KEY REFERENCES}

A full bibliography is in Appendix E. Inspectors and management will require access to:

Procedures for Post-Earthquake Safety Evaluation of Buildings

(Works Consultancy Ltd, 1990; published by Ministry of Civil Defence; revision pending)

Guidelines for Initial shoring or securing of damaged buildings following earthquake 
(Ian C Smith and partners, 1992; published by EQC)

also recommended are the David Hammond lectures (1995) published by the RedR organisation.

\section{SECTION TWO: PREPARING THE PLAN}

Successful implementation of the plan requires prior attention to all the items listed below. Detailed discussion of key items follows the checklist.

\subsection{PREPAREDNESS CHECKLIST}

Actioned?

\subsubsection{Appoint Building Evaluation Manager}

(BEM) and provide a job description

The BEM should then:

Establish earthquake damage scenarios

Identify and locate all critical facilities

Consider a strategy for prioritising Rapid Evaluations

Prepare the management structure and appoint Level 2 staff (cf. Fig 3)

Plan for requesting and co-ordinating additional inspector

Provide technical leadership

Identify and arrange for buildings to serve as headquarters

Specify field inspectors' team composition and reporting procedures

Develop linkages with other parties

Arrange for on-going inspector training

2.1.2 Appoint an Administration Officer (AO) and provide a job description

The Administration Officer should plan for:

The provision of adequate numbers of staff

Suitable office space and equipment

Providing necessary resources to all inspectors

Providing a method of tracking inspectors

The operation of information management systems

Adequate communications systems

Assisting visiting reconnaissance groups

On-going training of administrative staff

2.2

BEM Tasks

\subsection{1}

\section{Appointment of the BEM}

Before the event, two or three local persons qualified for the task should be identified, listed in call-out order and prepared for the responsibility by appropriate training. Mutual aid agreements should be entered into with one or more distant TAs since it must be assumed that local TA staff could be unavailable. They might be away, injured during the earthquake, or unavailable due to their family situations. Arrangements should be made for the provision of a suitably qualified BEM to come from another TA, unless specifically instructed otherwise.

\subsubsection{General responsibilities of the BEM}

The BEM reports to the Civil Defence Controller during an emergency, and is responsible for the safety evaluation of damaged buildings. A process for Rapid Evaluations and posting of all buildings in the damaged area is to be initiated as quickly as possible. Detailed Evaluations for structurally more complex or more important buildings, or those whose original classification warrants review, will also be required. Evaluations, together with their resultant posting are intended to reduce the likelihood of additional injuries to occupants, neighbours or passers-by from damaged buildings which could be further weakened by aftershocks. Requests for structural engineering assistance, to advise on shoring or temporary propping for example, are also likely from emergency services.

\section{Specific responsibilities of the BEM are outlined below.}

\subsubsection{Adopt earthquake damage scenarios}

One or more realistic earthquake damage scenarios must be adopted in order to appreciate the magnitude of the building safety evaluation task. For example, an earthquake risk assessment study of the Wellington region has been undertaken against two possible earthquake scenarios, enabling realistic estimates of the severity, extent and location of building damage. Resource and operational planning requirements can then be assessed.

\subsubsection{Prepare the management structure and appoint Level 2 staff}

The structure chosen must reflect the existing arrangements for inspection within that TA.

A suggested management structure is shown in Figure 3. Two or more Building Evaluation Officers (BEOs) and an Administration Officer report to the BEM. Each BEO could be responsible for one or more building types; for example, critical facilities, or commercial and industrial buildings, or domestic and residential buildings. However, in some situations it might be more appropriate for each BEO to control one geographic area. In most cases these Level 2 BEOs will personally manage and receive reports from field assessment teams, but some BEOs, such as in the domestic and residential area, may need deputies, each with responsibility for an area of the damaged region. Figure 3 assumes the domestic building stock is divided into four geographical quadrants.

The method of providing replacement or back-up personnel for the BEOs and the Administration Officer should follow the procedures suggested for a BEM. 


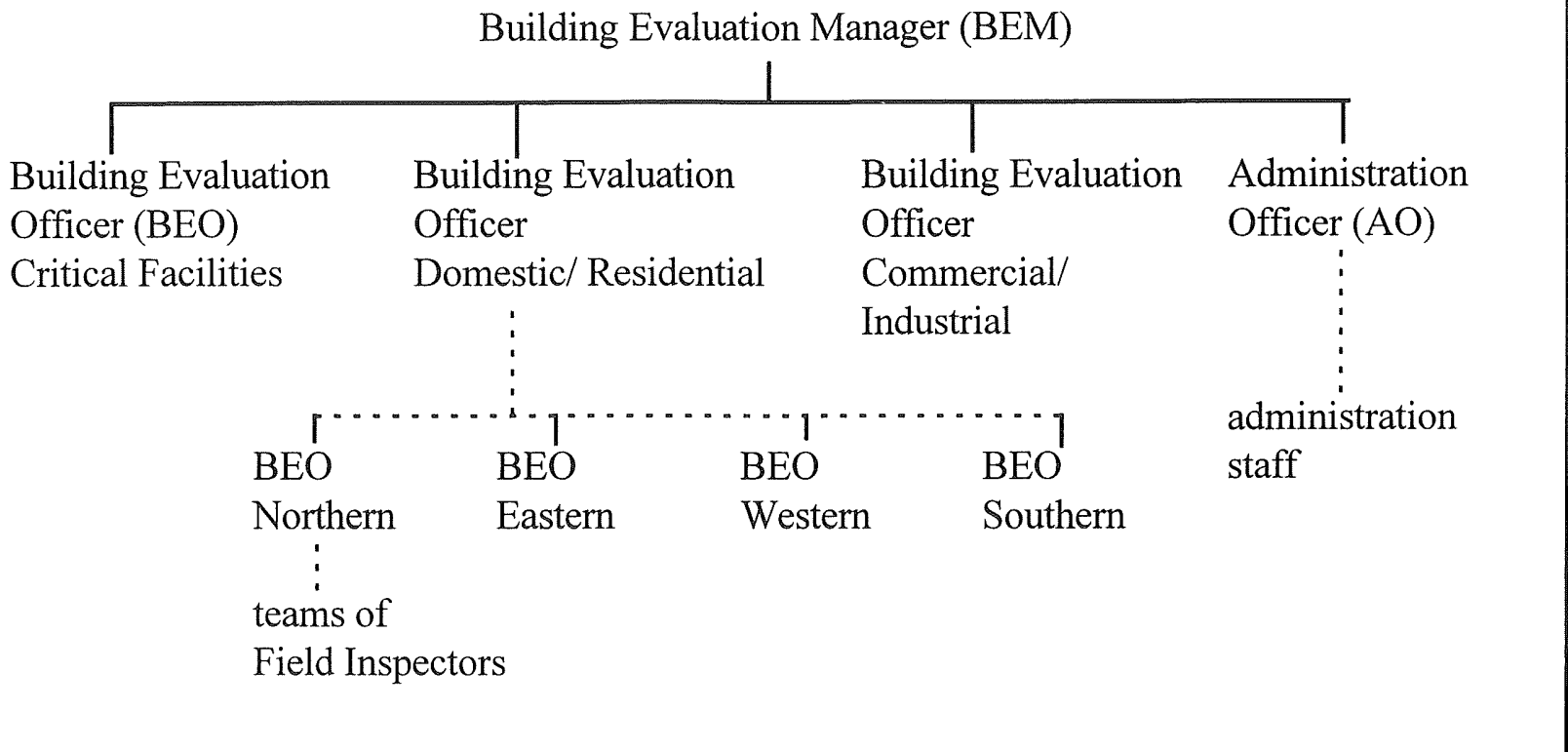

FIGURE 3: $\quad$ Suggested Management Structure

\subsubsection{Plan for requesting and co-ordinating additional inspectors}

The BEM is responsible for requesting technical personnel and co-ordinating their efforts to ensure they are being allocated in accordance with a preplanned priority strategy. Lists of locally available and qualified inspectors need to be at hand. These may be maintained either as lists of individuals and/ or as contact points for professional and other associations. Records must be arranged according to the kind of skills required.

For example, the BEO responsible for critical facilities requires structural, electrical and mechanical engineers to assist in an emergency. Similar lists of qualified personnel are needed for evaluation of commercial, industrial, domestic, residential and other buildings.

In a major event, local resources will prove inadequate. The priority is to establish the shortfall, specifying the requirement for each occupational group. Local authorities, who should have established resources available in their locality, are seen as the co-ordination point for such requests. The Ministry of Civil Defence will also assist with coordination. RedR ${ }^{1}$ maintains a register of skilled volunteers who could offer assistance

\subsubsection{Provide technical leadership}

The BEM must be thoroughly conversant with postearthquake building evaluation procedures in order to provide technical leadership to the BEOs. All personnel at the top two tiers of the management structure should have copies of, and be thoroughly familiar with the publications listed as "Key References" in section 1.6.

1 Register of Engineers for Disaster Relief Aotearoa (NZ)

\subsubsection{Identify and locate all critical facilities}

Critical facilities are those locations which provide services which the community needs to function effectively, and includes hospitals and utility providers. They need to be listed, located on a map, and their order of evaluation prioritised. Do not rely on personal local knowledge; this information is best documented. The possible difficulty of transport to and from these sites, and their relative geographical locations, require consideration. These buildings should be given immediate Detailed Evaluations by structural and building services engineers.

\subsubsection{Consider a strategy for prioritising Rapid Evaluations}

Critical facilities are the first priority but will be given Detailed Evaluations.

Commercial and industrial buildings. Individual facilities can be prioritised using criteria such as:

- adjacency to arterial routes

- adjacent pedestrian counts

- density of building

- importance of the enterprise

- presence of dangerous goods

- specific roles in the emergency or restoration phases of the earthquake

- storage or production of essential supplies

- restoration of normal commerce and employment

Street maps should be divided into priority areas on the basis of expected damage. Damage assessment and building posting would be undertaken on a street route or block by block basis. 
BEOs could consider plotting placard colours associated with each inspected building on a map as a graphic means of monitoring the progress of evaluations.

Domestic and residential areas. Some residential facilities will need priority evaluation in suburban areas. For example, designated civil defence gathering places, rest homes and other places of accommodation, schools and food distribution centres. However, evaluation teams should work through the damaged areas, according to the priorities established by the BEM. Some TAs have already undertaken earthquake risk assessment studies and identified areas likely to be more severely affected by ground shaking.

This damage assessment strategy should be as flexible as possible to respond to unexpected building damage distribution, requests from building owners and occupiers, other authorities such as the Police and Fire Service, and other unexpected situations.

\subsubsection{Identify and arrange for buildings to serve as headquarters}

A central building, expected to be serviceable after a major earthquake, is required for the BEM's headquarters. It should accommodate all necessary functions, including gathering of field staff for briefing and debriefing meetings. Some BEOs will need to identify other separate robust field headquarters located nearer to their geographical areas of responsibility.

\subsubsection{Specify team composition and reporting procedures for field inspectors}

Each inspection team ideally consists of two technical field staff and a person to attend to social needs. Field staff should report at least daily to their supervisor who would report once or twice daily to the BEM. Each team should have a means of communication, such as a cell phone. They should have priority access to their BEO, possibly via an unlisted number. Completed building assessment forms would be returned for data entry each day.

\subsubsection{Develop linkages with other parties}

There must be as much mutual agreement and co-operation as possible between all affected parties, including building insurers and EQC, who play a critical role in the disaster restoration phase. Duplication of technical and administration resources must be minimised. The BEM should also form linkages with selected contractors, local and distant, who can undertake temporary shoring works and building demolition. The maintenance of linkages should be ongoing, with contacts renewed at least annually.

\subsubsection{Arrange for on-going training}

At least annually, the BEM should arrange for appropriate TA staff, and as many other potential inspectors as possible, to undertake a training exercise. Participants could be credited with this training by having it noted against their names on any list of potential inspectors.

\subsection{RESPONSIBILITIES OF THE ADMINISTRATION OFFICER}

\subsubsection{General Responsibilities}

The Administration Officer (AO) has responsibility for all administrative aspects of the building safety evaluation task. At all times there will be close liaison with and frequent reporting to the BEM. The key responsibilities are to:

- Arrange for adequate numbers of staff

- Arrange for suitable office space and equipment

- Provide necessary resources to all inspectors

- Provide transport as required

- Arrange for support to staff members' families

Registration, processing and briefing material is required for all inspectors. A list of other documents and necessary equipment is given in Appendix $\mathrm{C}$.

Field staff will be expected to provide their own tools of the trade, such as hard hat, clipboard, dust mask, tape measure, compass, camera, torch etc. They can be expected to be available for up to five days maximum to avoid becoming overstressed, and then be replaced. The TA should take responsibility for providing inspectors with all local transport, accommodation and food. North American practice is not to pay salaries to additional inspectors during the emergency phase, but to ensure that all reasonable personal expenses are reimbursed.

The TA should ensure full legal immunity from civil liability for personal injury, death or property damage caused by non-wilful acts or omissions during their inspections. Section 66 of the Civil Defence Act 1983 covers only the period of a declared emergency; other arrangements need to be made for activities after its termination.

\subsubsection{Arrange a method for tracking inspectors}

Inspectors should always work in pairs, and their movements should be tracked for safety reasons. A log should be kept and regular daily contact maintained with headquarters.

\subsubsection{Prepare the operation of information management systems}

Meticulous record keeping, including personnel details, is essential. Inspectors will report on damaged buildings by using the pre-printed assessment forms. The $\mathrm{AO}$ arranges for filing of forms and the transfer of information into a purpose designed database, and generates a variety of reports as requested by the BEM. Damage cost estimates need to be calculated from the percentage damage figures, using the services of a building economist. Building assessment records may need to be later transferred to other parties, such as insurance companies, involved in restoration work. 


\subsubsection{Prepare adequate communications systems}

Managers should assume that telephone networks are disrupted for up to two weeks. Between the public and the BEM's headquarters, phone lines and staff will be required to take calls requesting evaluations of damaged buildings and to answer general queries from the public. An example of a form to be filled in by a telephonist is suggested in Appendix D. Between field inspectors and headquarters, one or more unlisted phone lines may be needed to maintain this communication channel.

Handouts for building owners and occupiers, as described in ATC 20-2, should also be prepared.

\subsubsection{Assist visiting scientific and technical reconnaissance groups.}

Provide assistance as appropriate and practicable. (Past New Zealand reconnaissance teams have often received valuable assistance). Very important information is obtained during all phases of an earthquake disaster, contributing to ongoing mitigation developments.

\subsubsection{Arrange on-going training}

An annual training exercise should be undertaken for administration staff.

\section{SECTION THREE:}

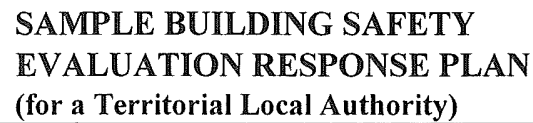

\subsection{AUTHORITY AND SCOPE}

3.1.1 This response plan is for the management of building safety inspections following an earthquake or other event that causes widespread property damage within [TA name].

3.1.2 This plan, and the persons responsible for its activation and implementation are referred to in [section] of the Territorial Authority's Civil Defence Plan.

3.1.3 This plan is intended to apply to the emergency response phase only. Another plan is required to manage the longer-term restoration period.

3.1.4 The officer of council appointed to manage this plan is [name or position]. The alternatives are [names or positions]. The position title, "Building Evaluation Manager" (BEM) is used to describe the task manager throughout this plan.

3.1.5 During a state of civil defence emergency, the persons named in this plan act as agents of the civil defence controller. Following termination of an emergency, normal management structures within the council are observed.

\section{ACTIVATION}

3.2.1 On the basis of initial damage reports provided for in the civil defence plan, the civil defence controller shall order the activation of this plan. The plan can also be activated by the responsible officer(s) of council, where evident damage to property demands it.

3.2.2 Activation authorises the convening of a committee whose members are responsible for appropriate emergency responses under their control. One member of this committee, responsible for building safety assessment, is the Building Evaluation Manager (BEM).

3.2.3 The BEM will activate a prepared management structure to facilitate Rapid and Detailed building safety evaluations, according to the provisions of this plan.

3.2.4 A co-ordination centre will be opened at [location] or [location]. If damage precludes the use of both of these facilities, alternative premises must be urgently obtained and the new location advised to the controller.

3.2.5 All staff activated under this plan are to report initially to the co-ordination centre or [another designated location].

\section{ORGANISATION AND STAFFING}

3.3.1 The outline organisation is as depicted in [cf. Figure 3 in 2.2.4]. The severity of the event will determine the number of Building Evaluation Officers (BEOs) and the division of tasks. Key responsibilities are listed below for each appointment.

\subsubsection{Building Evaluation Manager (BEM)}

- activation of this plan

- appointment of BEOs as required

- establishing inspection requirements and shortfalls

- requesting inspection resources as necessary

- providing technical leadership

- setting inspection priorities

- liaison with other agencies

- obtaining and promulgating summary reports

- providing advice to the controller or chief executive as appropriate

\subsubsection{Building Evaluation Officer (BEO)}

- manage inspection teams

- arrange inspection schedules

- report on progress 
3.3.4 Administration Officer (AO)

- provide and manage support staff

- arrange location, support services and resources for the inspection process

- establish public "call centre" to record inspection requests

- establish and maintain inspection database

- provide communications

- maintain tracking system for inspectors

- assist with hosting of visiting reconnaissance groups

\subsubsection{Inspectors}

- report to BEM as soon as practical after the event

(family or contractual reasons may impose delays)

- conduct rapid and detailed inspections as directed

- provide records at the end of each day

- alert BEOs to any problems observed.

\subsection{OUTLINE PROCEDURES}

\subsubsection{Priority Sequence}

- Plan Activated

- Staff report to BEM

- Ascertain extent and distribution of property damage

- Appoint BEOs and allocate priority tasks

- Establish inspector resource shortfall and request support

- Initiate detailed inspections of critical facilities

- Establish "call centre" for inspection requests

- Activate database

- Commence rapid inspections on block by block basis

- Record and report progress

\subsubsection{Ascertain extent and distribution of property damage}

Locality maps are provided either in Geographic Information Systems (GIS) format by [council department] $o r$ in hard copy form by [council department]. Contact must be made with the [intelligence or information officer] at the civil defence headquarters, if the HQ is established. Copies of building damage reports should be provided to the BEM. Initially, a member of the inspection staff may be sent to the $\mathrm{CD}$ headquarters to act as a liaison person. This information may need to be supplemented by requiring cursory inspection of priority areas.
As reports are received, the summary information needs to be plotted on to maps. The aim is to identify which parts of the $[T A$ name $]$ have suffered significant property damage, and to rank those areas in terms of overall severity.

\subsubsection{Establish public "call centre".}

A "call centre" is established to receive and process requests for inspections. Once phone lines are restored, and help numbers are advertised, this will attract a high volume of calls. A front desk facility, where members of the public and/ or visiting inspectors can call in, is a useful addition. This centre should normally be established close to, but not within, the BEM's office area.

\subsubsection{Activate database}

The inspection database has to record and report on:

- damage reports

- requests for inspection and reinspection

- allocated tasks

- progress of building assessments, by category, area etc.

The fields within the database must reflect the information sought in the Telephonist or Counter Enquiry forms [ $c f$. Appendix D], and the rapid and detailed assessment forms [Appendix A]

\subsubsection{Commence Rapid Inspections}

Inspections are conducted according to the procedures outlined in the references. Inspectors report at the beginning (and conclusion) of each day, to receive tasks and provide reports. Detailed inspections are usually allocated as individual premises; rapid inspections are normally done on an area basis.

\subsubsection{Record and Report Progress}

The database is used to keep records against individual buildings, and to report on trends and summaries. For example, a critical facility may be inspected more than once; or progress on clearing residential properties may be monitored; or estimates of total loss may be sought by comparing reports on commercial properties with the rating base.

Information from the assessment process will also be sought by other parties such as insurance companies and disaster researchers, who may contribute to later operational phases of the disaster. 
3.5 ADMINISTRATION

\subsubsection{General Support Requirements}

In an emergency situation, the administration officer provides a variety of support services. For example, liaison with civil defence welfare may be required to arrange catering for inspectors. The provision of placards, forms and reference materials is also essential. In addition, the BEM's office must be set up to run efficiently.

\subsubsection{Responsibility for Inspectors}

Given that inspectors will be working under stress, and in potentially dangerous conditions, care must be taken to ensure:

- inspectors work in pairs

- all inspectors are accounted for daily

- debriefing facilities are made available

- inspectors are well briefed on safety issues

- next of kin details are maintained

- inspectors are replaced after five to six days on duty

\subsubsection{The BEM's Office}

Roles which need to be allocated by the administration officer include:

- welfare officer (for inspectors and other staff)

- requests clerk (handling incoming calls)

- records clerk (responsible for database)

The allocation of persons will reflect the size of the task at hand.

\subsection{MATERIAL REQUIREMENTS}

\subsubsection{Inspector Requirements}

These are listed in Appendix C.

\subsubsection{Material Provision}

The administration officer must arrange for the production of the necessary:

- placards (from water resistant nonfading material such as Tyvek)

- indelible nonfading marker pens

- inspector identification

- briefing sheets

- assessment forms

- inspector handbooks

to make up any shortfall. 


\section{RAPID Evaluation Safety Assessment Form}

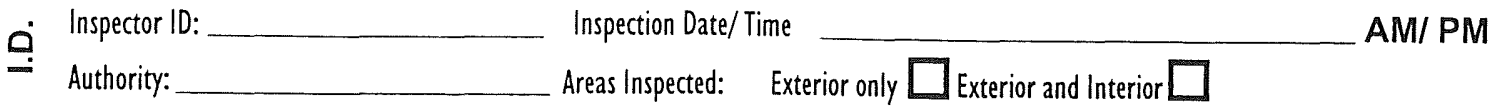

Inspector 1D:

Inspection Date/ Time

AM/ PM

Authority: Areas Inspected: Exterior only $\square$ Exterior and Interior $\square$

Z Building Name

Address

Contact name

Contact Phone

Stories above ground: $\square$ below ground: $\square$

Typical floor area $\left(\mathrm{m}^{2}\right)$ :

No. of residential units

No. of residential units not habitable:

Type of Construction

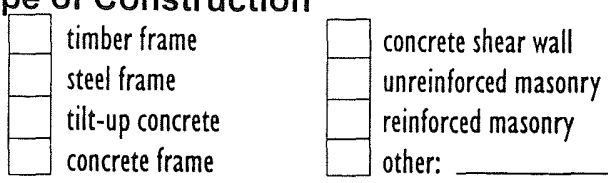

Primary Occupancy

$\square \begin{aligned} & \text { dwelling } \\ & \text { other residential } \\ & \text { public assembly } \\ & \text { emergency service }\end{aligned} \quad \square \quad \square \begin{aligned} & \begin{array}{l}\text { commercial } \\ \text { offices } \\ \text { industrial } \\ \text { other: }\end{array} \\ & \text { ether }\end{aligned} \quad \square \begin{aligned} & \text { government } \\ & \text { heritage } \\ & \text { school }\end{aligned}$

Investigate the building for the conditions listed and check the appropriate column.

\section{Observed Conditions}

collapse, partial collapse, or building off foundation

을 building or storey leaning

racking damage to walls, other structural damage

chimney, parapet, or other falling hazard

ground slope movement or cracking

other* (specify)

Comments:

Minorl

None Moderat
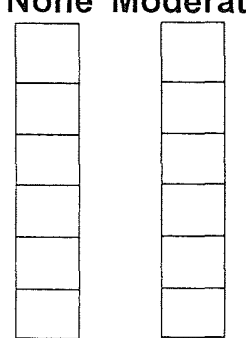

Estimated building Damage (excluding contents)

$\square$ none
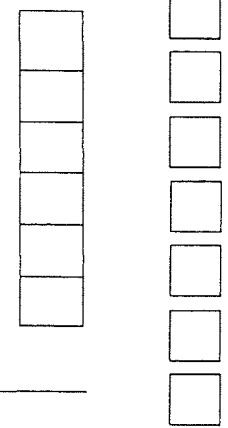

$0.1 \%$

$2-10 \%$

II $-30 \%$

$31-60 \%$

$61-99 \%$

$100 \%$

* investigate site hazards such as gas, electricity, sanitary sewer, stormwater or toxic materials

Choose a posting based on the evaluation and team judgement. Severe conditions affecting the whole building are grounds for an UNSAFE posting. Localised severe and overall moderate conditions may require a RESTRICTED USE or SHORT TERM ENTRY posting.

足

Post INSPECTED placard at main entrance. Post all other placards at every significant entrance.
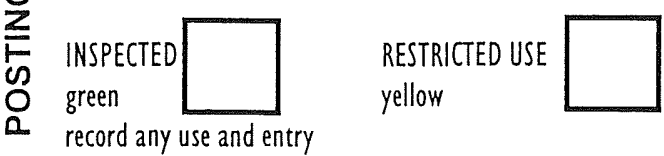

SHORT PERIOD ENTRY orange

UNSAFE

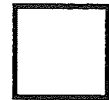

red

restrictions exactly as

written on the placard:

tick the boxes below only if further actions are recommended:

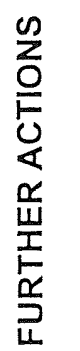

barricades are needed in the following areas:

$\square$ detailed evaluation recommended: $\square$ structural $\square$ geotechnical $\square$ other:

other recommendations:

comments: 


\section{DFAMI ED Evaluation Safety Assessment Form}

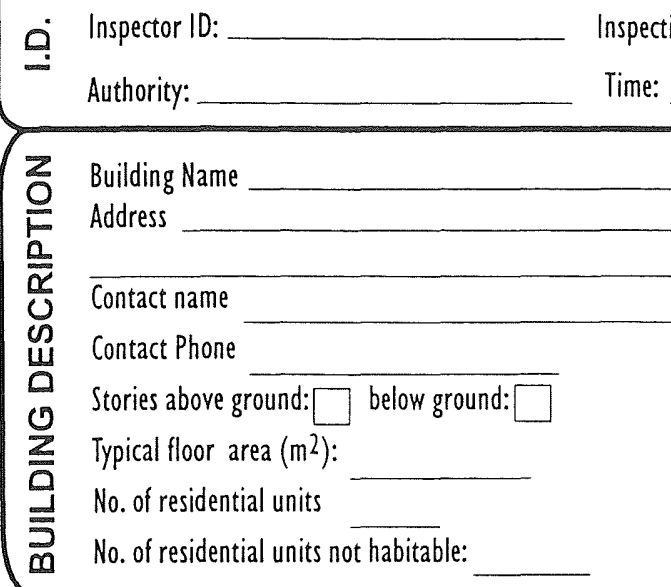

Time:

Building Name Address

Contact name

Contact Phone

Stories above ground: $\square$ below ground: $\square$

Typical floor area $\left(\mathrm{m}^{2}\right)$ :

No. of residential units

No. of residential units not habitable: AM/PM

Type of Construction

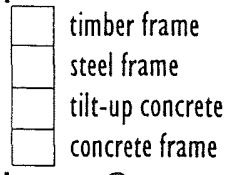

Primary Occupancy

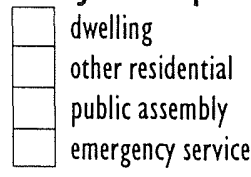

$\square$ concrete shear wall unreinforced masonry

reinforced masonry

other:

$\square \begin{aligned} & \begin{array}{l}\text { commercial } \\ \text { offices } \\ \text { industrial } \\ \text { other: }\end{array} \\ & \square\end{aligned} \square \begin{aligned} & \text { government } \\ & \text { heritage } \\ & \text { school }\end{aligned}$

Investigate the building for the conditions listed and check the appropriate column. A sketch may be added on page 2 .

Overall Hazards Minor/None Moderate Severe Comments

collapse, or partial collapse

building or storey leaning

Other:
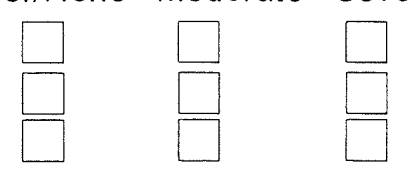

\section{Structural Hazards}

foundations

roofs, floors (vertical loads)

columns, pilasters, corbels

diaphrams, horizontal bracing

walls, vertical bracing

precast connections

other:

\section{Z Nonstructural hazards}

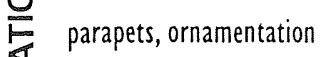

$S$ cladding, glazing

$\leqslant$ ceilings, light fixtures

interior walls, partitions

elevators

stairs, exits

Utilities*

other:

\section{Geotechnical hazards}

slope failure, debris

ground movement, fissures

other:
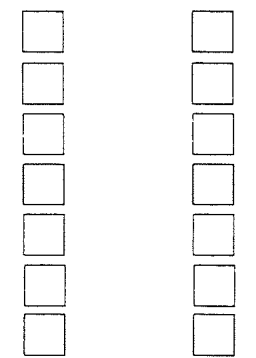

General Comments:
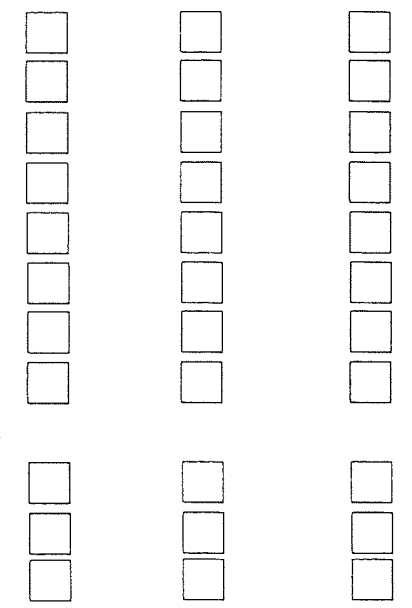

* investigate site hazards such as gas, electricity, sanitary sewer, stormwater or toxic materials 


\section{DEAILED Evaluation Safety Assessment Form: Page 2}

Inspector ID:

Building Address:

Sketch (optional)

provide a sketch of the entire building or damaged portions. Indicate damage points.

Estimated building Damage (excluding contents)
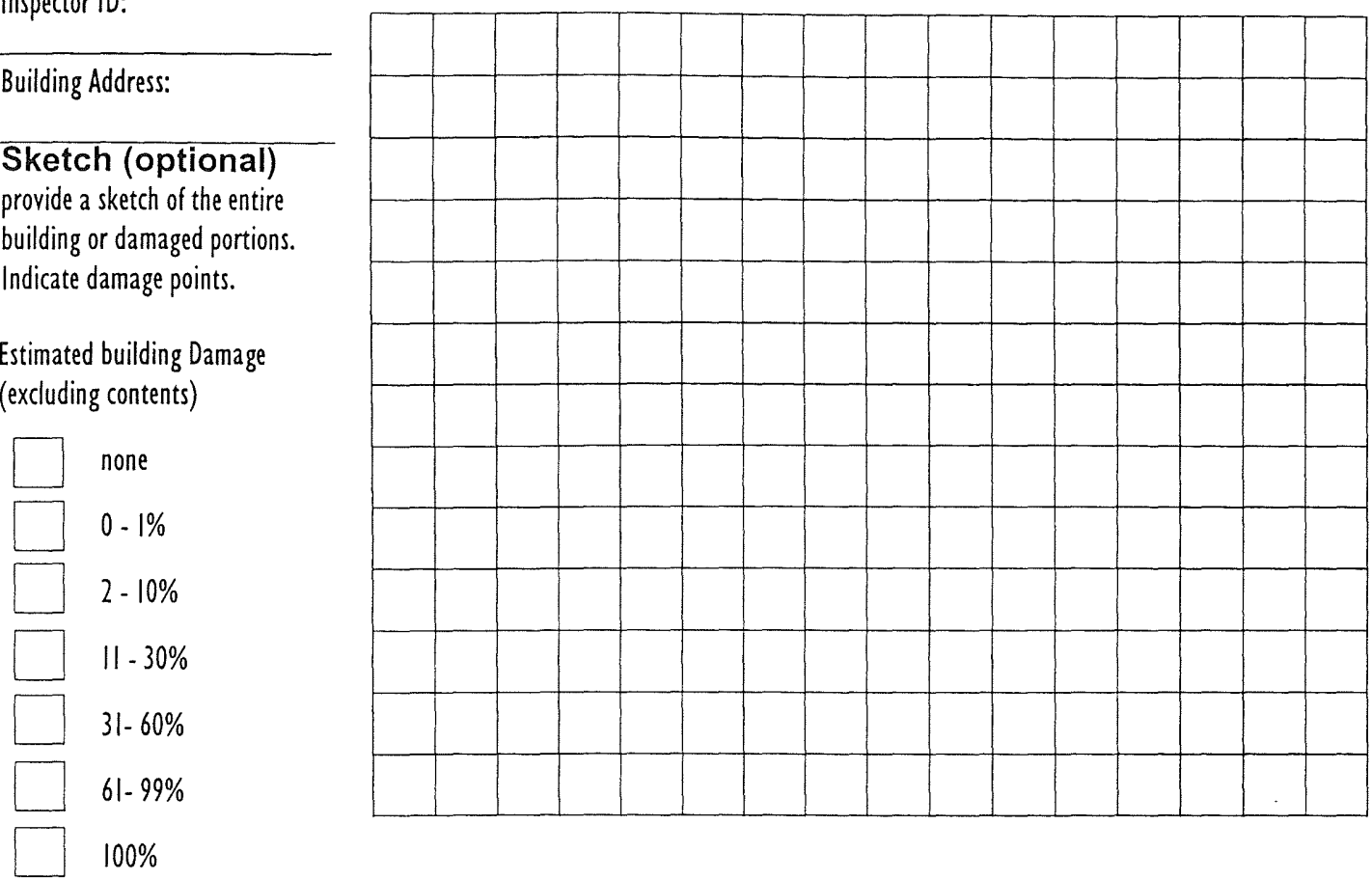

$100 \%$

Record any existing placard on this building

Choose a new posting based on the new evaluation and team judgement. Severe conditions affecting the whole building are grounds for an (1) UNSAFE posting. Localised severe and overall moderate conditions may require a RESTRICTED USE or SHORT TERM ENTRY posting. POSt INSPECTED placard at main entrance. Post all other placards at every significant entrance. Transfer the posting chosen to page one (top).

E

green

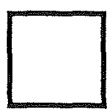

RESTRICTED USE

yellow

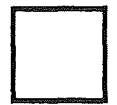

SHORT PERIOD ENTRY orange

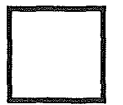

UNSAFE

red

record any use and entry

restrictions exactly as written

on the placard:

tick the boxes below only if further actions are recommended:

$\square$ barricades are needed in the following areas:

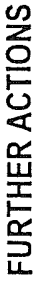

Engineering evaluation recommended:

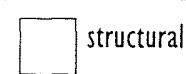

geotechnical

other:

$\square$ other recommendations:

comments: 


\section{IN S P E C T E D \\ NO RESTRICTION ON USE OR OCCUPANCY}

This building has been inspected and no apparent structural hazard has been found.

\section{$\square \quad$ Exterior Only \\ Exterior and Interior}

Facility Name and Address:

Report any unsafe conditions to Territorial Authorities. Subsequent events causing damage may change this assessment. Reinspection may be required. Secondary damage (partitions, windows, fittings and furnishings) may be hazardous. Electrical and mechanical equipment, water supplies and sanitary facilities have not been inspected.
This facility was inspected pursuant to (Act):

Inspector ID:

Acting on Authority of:

Date:

Time:

\section{RESTRICTED USE NO ENTRY EXCEPT ON ESSENTIAL BUSINESS}

\section{WARNING:}

This building has been damaged and its structural safety is questionable. Earthquake aftershocks present danger. Enter only at own risk. Subsequent events may result in increased damage and danger, changing this assessment. Reinspection may be required. The damage is as described below:

\section{Restrictions on use:}

- No public entry nor residential occupation

- Entry for

$\square$ emergency purposes

$\square$ damage assessments, making safe

$\square$ conducting essential business with minimum staff
Facility Name and Address:

This facility was inspected pursuant to (Act):

Inspector ID:

Acting on authority of:

Date:

Time: 


\section{SHORT PERIOD ENTRY \\ NO SUSTAINED USE OR OCCUPATION PERMITTED}

WARNING:

This building has been damaged and its structural safety is questionable. Earthquake aftershocks present danger. Enter only at own risk. Subsequent events may result in increased damage and danger, changing this assessment. Reinspection may be required. The damage is as described below:

This facility was inspected pursuant to (Act):

Inspector ID:

Acting on authority of:

Date:

Time:

- No public entry nor residential occupation

- Entry for:
$\square$ emergency purposes
$\square$ damage assessments, making safe
$\square$ removal of essential business records
$\square$ removal of valuables only

Facility Name and Address:

\section{Do Not Remove this Placard. Placed by order of the Territorial Authority}

\section{UNSAFE \\ DO NOT ENTER OR OCCUPY}

WARNING:

This building has been seriously damaged and is unsafe. Do not enter. Entry may result in death or injury. The damage is as described below:-

Entry only on specific written authorisation from Territorial Authority.

Facility Name and Address:
Date:

Time:

This facility was inspected pursuant to (Act):

Inspector ID:

Acting on authority of:

Do Not Remove this Placard. Placed by order of the Territorial Authority 


\section{APPENDIX C:}

\section{LIST OF ESSENTIAL ITEMS TO BE PROVIDEDTO INSPECTORS}

Official identification/ field passes (secure
clip-on badges)
Written authority to enter properties
Distinctive protective clothing (Eg Orange
coloured vests)
Street maps
Forms for rapid and detailed building
evaluations
Placards
Security cordoning tape
Thumb tacks and masking tape for placards
Briefing Sheets:
outline procedures
reporting requirement
contact points
(etc)
- $\quad$ Office supplies
Cell phones (where possible)
Horch and batteries
Protective gloves
-

\section{APPENDIX D:}

\section{EXAMPLE TELEPHONIST'S FORM}

\section{INSPECTION REQUEST - STANDARD QUESTIONS}

Hello, you have reached the [name of council]'s Building Evaluation Control Centre.

[Your name] speaking.

Do you want to request a damage inspection? (if Yes) I am about to ask you a series of questions about your building. Please respond only to the questions asked. This will help speed up your request for inspection.

(if $\mathrm{No}$ ) How may I help you?

1. What is the address of the building? Unit No?

2. What is your name?

3. What is your normal telephone number? Is it working now? Contact no. if not?

4. Are you the: Owner? Tenant? Other?
Other Agency? (eg) Fire? Police? Water, Gas or Electricity?

5. How is the building used:
Flats?
Office?
Commercial? School?

Dwelling?

ow many stories above ground?

7. What kind of construction is your building?

$\begin{array}{ll}\text { Timber frame? } & \text { Masonry/Concrete? } \\ \text { Steel? } & \text { Other? }\end{array}$

8. Does the inspector need to go inside? (Y/N) (If yes, someone to let the inspector in)

Access contact person:

Address

Telephone no.

9. Is any part of your building collapsed? $(\mathrm{Y} / \mathrm{N})$

10. Is any part of your building leaning or off the foundation? $(\mathrm{Y} / \mathrm{N})$

11. Is there any falling hazard? (Y/N)

12. Is there any severe cracking? ( $\mathrm{Y} / \mathrm{N})$

13. Are any of your utilities damaged? Water $(\mathrm{Y} / \mathrm{N}) \mathrm{Gas}$ $(\mathrm{Y} / \mathrm{N})$ Electricity $(\mathrm{Y} / \mathrm{N})$

Sewerage $(\mathrm{Y} / \mathrm{N})$

14. Is your building in any danger from buildings next door? $(\mathrm{Y} / \mathrm{N})$ Does it endanger other buildings? (Y/N)

15. Does the ground have any settlement or any cracks? $(\mathrm{Y} / \mathrm{N})$

16. Other than this inspection, do you need any other help? $(\mathrm{Y} / \mathrm{N})$ (if so, what kind?)

17. Please contact your Insurance Company

Thank you for helping me to speed up your inspection response.

If you have any further questions please call [council agency] at [phone number or location]

List any pertinent information the field inspector may need:

Taken by:

Date:

Time: $\quad \square$ am $\square \mathrm{pm}$

\section{APPENDIX E:}

\section{BIBLIOGRAPHY}

Bent, D., (1993). Local Authorities and earthquakes - some guidance for councillors and managers, Ministry of Civil Defence, Wellington.

Hammond, D., (1995). David Hammond lectures 1995 - urban search and rescue, structural collapse, building triage, Register of Engineers for Disaster Relief NZ, Auckland.

Ian C Smith \& Partners, (1992). Guidelines for initial shoring or securing of damaged buildings following earthquake, Earthquake and War Damage Commission, Wellington.

Works Consultancy Services, (1995). Earthquake risk assessment study. Study area 1 - Wellington City. Wellington Regional Council, Wellington. 
Works Consultancy Ltd, (1990). Procedures for post-earthquake safety evaluation of buildings. (Adapted from ATC-20). New Zealand Ministry of Civil Defence, Wellington.

- 1995. Wellington City disaster recovery planning guide. Wellington City Council Wellington Emergency Management Office.

- 1989. ATC-20 Procedures for postearthquake safety evaluation of buildings, Applied Technology Council, Redwood City, California.

- 1995. ATC-20-2 Addendum to the ATC-20 postearthquake building safety procedures, Applied Technology Council, Redwood City, California.

- 1991. Building department guide to disaster mitigation, International Conference of Building Officials, Whittier, California.

- 1991. Disaster response procedural manual, City of Long Beach California Department of Planning and Building (Unpublished).

- 1992. Post-disaster safety assessment plan: Local building officials' guide to the activation and utilization of safety assessment volunteers, State of California Governor's Office of Emergency Services, (unpublished) Sacramento, California. 